\title{
Constructing $\mathrm{CdS} / \mathrm{Cd} /$ doped $\mathrm{TiO}_{2}$ Z-scheme type visible light photocatalyst for $\mathrm{H}_{2}$ production
}

\author{
Zhao Zhao ${ }^{1,2,3,4}$, Yanbo Xing ${ }^{1}$, Haibo Li $^{1}$, Pingyun Feng ${ }^{4^{*}}$ and Zaicheng Sun ${ }^{2^{*}}$
}

\begin{abstract}
Constructing Z-scheme type photocatalyst is an efficient way to improve the charge separation efficiency and enhance the photocatalytic activity. In this report, the $\mathrm{Cd}_{\mathbf{T}} \mathrm{TiO}_{2}$ nanoparticles are prepared via the sol-gel route and employed as a starting material. When it was reduced by $\mathrm{NaBH}_{4}$ at $300^{\circ} \mathrm{C}$, the surface oxygen vacancies were produced and $\mathrm{Cd}^{2+}$ was reduced into metal $\mathrm{Cd}^{0}$ nanoparticle (denoted as $\mathrm{R}-\mathrm{Cd}: \mathrm{TiO}_{2}$ ). Subsequently, the formed R-Cd: $\mathrm{TiO}_{2}$ was treated with thioureain the hydrothermal reaction. Through the decomposition of thiourea, the oxygen vacancies were refilled by $\mathrm{S}^{2-}$ from thiourea to form $\mathrm{S}: \mathrm{TiO}_{2} / \mathrm{TiO}_{2}\left(\mathrm{~d}-\mathrm{TiO}_{2}\right)$ and $\mathrm{Cd}$ was partially converted into $\mathrm{CdS}$ to form $\mathrm{CdS} / \mathrm{Cd} / \mathrm{d}-\mathrm{TiO}_{2}$ composite. The formed $\mathrm{CdS} / \mathrm{Cd} / \mathrm{d}-\mathrm{TiO}_{2}$ composite exhibits improved photocatalytic activity. Under visible light irradiation $(\lambda>400 \mathrm{~nm})$, the $\mathrm{H}_{2}$ production rate of $\mathrm{CdS} / \mathrm{Cd} / \mathrm{d}-\mathrm{TiO}_{2}$ reaches $119 \mu \mathrm{mol} \mathrm{h}^{-1}$ with $50 \mathrm{mg}$ of photocatalyst without any cocatalyst, which is about 200 and 60 times higher than that of $\mathrm{S}: \mathrm{TiO}_{2} / \mathrm{TiO}_{2}$ $\left(0.57 \mu \mathrm{mol} \mathrm{h}^{-1}\right), \mathrm{CdS}\left(2.03 \mu \mathrm{mol} \mathrm{h}{ }^{-1}\right)$ and heterojunction CdS/ ${\mathrm{d}-\mathrm{TiO}_{2}}_{2}\left(2.17 \mu \mathrm{mol} \mathrm{h}^{-1}\right)$ materials, respectively. The results illustrate that metal $\mathrm{Cd}$ greatly promotes the charge separation efficiency due to the formation of $\mathrm{Z}$-scheme type composite. In addition, the photocatalytic activity in the visible light region was dramatically enhanced due to the contribution of both $\mathrm{CdS}$ and $\mathrm{d}-\mathrm{TiO}_{2}$. The method could be easily extended to other wide bandgap semiconductors for constructing visible light responsive $\mathrm{Z}$-scheme type photocatalysts.
\end{abstract}

Keywords: Z-scheme, CdS, doped $\mathrm{TiO}_{2}, \mathrm{Cd}, \mathrm{H}_{2}$ production

\section{INTRODUCTION}

With increasing demands for alternative sources of fuel, extensive research has focused on the discovery of methods to generate renewable energy from solar energy. Photocatalytic water splitting using inorganic semiconductors is a potentially scalable and economically feasible technology for converting solar energy into hydrogen for fuel cells [1-6]. In recent years, a wide range of inorganic nanomaterials and nanostructures with tunable band gaps have been synthesized and used as photocatalysts for splitting water into hydrogen and oxygen. In addition to generating new materials with narrow band gap, highly efficient charge separation architectures are also desirable to promote the performance of photocatalysts. For example, the design and synthesis of heterojunction Z-scheme architectures have attracted great attention recently [7-11]. This is because the Z-scheme type photocatalytic system, which mimics natural photosynthesis process, retains the reduction capability in the photosystem I (PSI), oxidation capability of photosystem II (PSII) and broad light absorption of both PSI and PSII.

$\mathrm{Up}$ to date, three kinds of Z-schemes were developed based on the charge transfer mediator including redox mediators, metal, and direct contact [12-15]. In 2006, Tada and co-workers [16] reported $\mathrm{CdS} / \mathrm{Au} / \mathrm{TiO}_{2}$ all solid-state Z-scheme, which employed CdS as PSI photocatalyst, $\mathrm{TiO}_{2}$ as PSII photocatalyst and $\mathrm{Au}$ as electron mediator. After that, different solid state Z-schemes were extensively investigated. Many semiconductors such as, $\mathrm{CdS}[17,18], \mathrm{AgX}[19], \mathrm{g}^{-} \mathrm{C}_{3} \mathrm{~N}_{4}$ [20], $\mathrm{Cu}_{2} \mathrm{O}$ [21], doped $\mathrm{SrTiO}_{3}$ [22], $\mathrm{CuGaS}_{2}$ [23] and others were employed as PSI photocatalyst. Most PSII photocatalysts were chosen from $\mathrm{TiO}_{2}$ [24], $\mathrm{ZnO}$ [25], $\mathrm{WO}_{3}$ [26], $\mathrm{Ag}_{3} \mathrm{PO}_{4}$ [27], $\mathrm{BiVO}_{4}$

\footnotetext{
${ }^{1}$ Key Laboratory of Functional Materials Physics and Chemistry of the Ministry of Education, Jilin Normal University, Changchun 130103, China ${ }^{2}$ Beijing Key Lab for Green Catalysis and Separation, Department of Chemistry and Chemical Engineering, College of Environmental and Energy Engineering, Beijing University of Technology, Beijing 100124, China

${ }^{3}$ State Key Laboratory of Electroanalytical Chemistry, Engineering Laboratory for Modern Analytical Techniques, Changchun Institute of Applied Chemistry, Chinese Academy of Sciences, Changchun 130022, China

${ }^{4}$ Department of Chemistry, University of California, Riverside, CA 99025, USA

* Corresponding authors (emails: pingyun.feng@ucr.edu (Feng P); sunzc@bjut.edu.cn (Sun Z))
} 
[28], etc. The common electron mediators used were $\mathrm{Au}$ [29], Ag [30], $\mathrm{Cu}$ [31] and reduced graphene oxide (RGO) $[28,32]$. The working principle of Z-scheme is that the light irradiates on both PSI and PSII photocatalysts and then the charge recombination happens between excited electrons from PSII and holes from PSI. As a result, the electrons in conduction band of PSI are available for the reduction reaction and holes in valance band of PSII are ready for oxidation reaction.

It is well known that $\mathrm{CdS}$ is a typical visible light photocatalyst, whereas $\mathrm{TiO}_{2}$ is a UV light responsive photocatalyst due to its large band gap. In the case of the solid-state Z-scheme nanostructure of $\mathrm{CdS} / \mathrm{Au} / \mathrm{TiO}_{2}, \mathrm{Z}$ scheme works only in the UV light region; it works only as a heterojunction but not Z-Scheme in the visible light region due to no excited electron from $\mathrm{TiO}_{2}$ in the visible light region. In order to construct visible-light responsive Z-Scheme, both PSI and PSII photocatalysts need to have visible light absorption. One way to achieve this is to use narrow band gap semiconductors such as $\mathrm{Ag}_{3} \mathrm{PO}_{4}$ or $\mathrm{BiVO}_{4}$ as PSII photocatalysts $[27,33]$. However, these materials suffer from the low chemical- and photo- stability. Considering the outstanding thermal- and photostability of $\mathrm{TiO}_{2}$, doped $\mathrm{TiO}_{2}$ can be an excellent candidate as the visible light responsive PSII photocatalyst.

In this report, we develop a new Z-scheme type heterostructure by reducing $\mathrm{Cd}$ doped $\mathrm{TiO}_{2}\left(\mathrm{Cd}: \mathrm{TiO}_{2}\right)$ nanoparticles (NPs) to form metal Cd NPs on the surface of $\mathrm{TiO}_{2}$. Subsequently by vulcanizing with thiourea, the $\mathrm{Cd}$ NPs are partially converted to CdS leading to the formation of $\mathrm{CdS} / \mathrm{Cd} /$ doped $\mathrm{TiO}_{2}$ composite heterostructure. The heterostructure consists of $\mathrm{CdS}$ shell and metal Cd core NPs on the surface of $\mathrm{TiO}_{2}$. Accompanying with this processing, it also promotes the formation of $\mathrm{S}$ doped $\mathrm{TiO}_{2}\left(\mathrm{~S}: \mathrm{TiO}_{2} / \mathrm{TiO}_{2}\right)$. The $\mathrm{S}: \mathrm{TiO}_{2} / \mathrm{TiO}{ }_{2}$ is represented as $\mathrm{d}-\mathrm{TiO}_{2}$. So the formed composite $(\mathrm{CdS} / \mathrm{Cd} / \mathrm{S}$ : $\mathrm{TiO}_{2} / \mathrm{TiO}_{2}$ ) is denoted as $\mathrm{CdS} / \mathrm{Cd} / \mathrm{d}-\mathrm{TiO}_{2}$. Without loading any cocatalysts, the formed $\mathrm{CdS} / \mathrm{Cd} / \mathrm{d}-\mathrm{TiO}_{2}$ composite exhibits highly efficient $\mathrm{H}_{2}$ production rates of 227 and $120 \mu \mathrm{mol} \mathrm{h}^{-1}$ under AM1.5 and visible light irradiation, respectively. The photocatalytic activity of $\mathrm{CdS} / \mathrm{Cd} /$ $\mathrm{d}-\mathrm{TiO}_{2}$ is more than 10 times highter than that of pure CdS, S: $\mathrm{TiO}_{2} / \mathrm{TiO}_{2}$ and $\mathrm{CdS} / \mathrm{d}-\mathrm{TiO}_{2}$ heterojunction in the visible light region $(\lambda>400 \mathrm{~nm})$.

\section{EXPERIMENTAL SECTION}

\section{Materials and chemicals}

Titanium(IV) butoxide (TBT, 97\%), cadmium acetate dehydrate (>98\%), hydrazine hydrate solution (78\%-
$82 \%)$, thiourea $(>99 \%)$, cadmium sulfide powder $(>98 \%)$, Pluronic ${ }^{\ominus} \mathrm{F}-127$ and $\mathrm{NaBH}_{4}(>98 \%)$ were purchased from Sigma-Aldrich Company. Concentrated hydrochloric acid (37\% by weight), acetic acid $(99.7 \%)$, ethanol (AR), and methanol (AR) were purchased from Fisher Scientific, and used as received without any further purification.

\section{Preparation of $\mathrm{TiO}_{2} \mathrm{NPs}$}

Mesoporous $\mathrm{TiO}_{2} \mathrm{NPs}$ were prepared through a modified sol-gel method using triblock copolymer as the structure directing agent $[34,35]$. In a typical reaction, $1.6 \mathrm{~g} \mathrm{~F}-127$, $3.5 \mathrm{~mL}$ TBT, $2.3 \mathrm{~mL} \mathrm{HAc}$, and $0.7 \mathrm{~mL} \mathrm{HCl}$ were dissolved in $30 \mathrm{~mL}$ ethanol under magnetic stirring for $60 \mathrm{~min}$, and then was transferred into a $60^{\circ} \mathrm{C}$ oven to evaporate ethanol for $24 \mathrm{~h}$. The as-prepared gel was calcined at $450^{\circ} \mathrm{C}$ in air for $4 \mathrm{~h}$ using a heating rate of $5^{\circ} \mathrm{C} \mathrm{min}^{-1}$ to remove the surfactant and to obtain ordered mesoporous $\mathrm{TiO}_{2}$ NPs.

\section{Preparation of Cd-doped $\mathrm{TiO}_{2} \mathrm{NPs}\left(\mathrm{Cd}: \mathrm{TiO}_{2} \mathrm{NPs}\right)$}

In a typical reaction, $1.6 \mathrm{~g} \mathrm{~F}-127,3.5 \mathrm{~mL}$ of TBT $(\sim 10 \mathrm{mmol}), 2.3 \mathrm{~mL} \mathrm{HAc}, 0.7 \mathrm{~mL} \mathrm{HCl}$ and a certain amount of $\mathrm{Cd}(\mathrm{Ac})_{2}(0.1-1 \mathrm{mmol})$ were dissolved in $30 \mathrm{~mL}$ ethanol under magnetic stirring for $60 \mathrm{~min}$, and then the sol-gel precursor was transferred into a $60^{\circ} \mathrm{C}$ oven to evaporate ethanol for $24 \mathrm{~h}$. The as-prepared gel was calcined at $450^{\circ} \mathrm{C}$ in air for $4 \mathrm{~h}$ using a heating rate of $5^{\circ} \mathrm{C} \mathrm{min}{ }^{-1}$ to remove the surfactant and to obtain ordered mesoporous $\mathrm{TiO}_{2}$ NPs.

\section{Preparation of reduced mesoporous $\mathrm{Cd} / \mathrm{TiO}_{2} \mathrm{NPs}$ (R-Cd: $\mathrm{TiO}_{2} \mathrm{NPs}$ )}

At room temperature, the mesoporous Cd-doped $\mathrm{TiO}_{2}$ NPs was mixed with $\mathrm{NaBH}_{4}$ at a molar ratio of 2:1 and then grounded for 30 min thoroughly. Then the mixture was transferred into a porcelain boat, and placed in a tubular furnace, heated from room temperature to $300^{\circ} \mathrm{C}$ under Ar atmosphere at a heating rate of $10^{\circ} \mathrm{C} \mathrm{min}{ }^{-1}$ and then hold for a designed time. After naturally cooling down to room temperature, the final product was simply washed with deionized water and ethanol for several times to remove unreacted $\mathrm{NaBH}_{4}$, and dried at $70^{\circ} \mathrm{C}$ in electronic oven. The reduced mesoporous $\mathrm{TiO}_{2} \mathrm{NPs}$ (R$\mathrm{TiO}_{2} \mathrm{NPs}$ ) were also prepared as the same procedure by using mesoporous $\mathrm{TiO}_{2} \mathrm{NPs}$ instead of mesoporous Cddoped $\mathrm{TiO}_{2} \mathrm{NPs}$.

Preparation of mesoporous $\mathrm{CdS} / \mathrm{Cd} / \mathrm{d}-\mathrm{TiO}_{2} \mathrm{NPs}(\mathrm{CdS} / \mathrm{Cd} / \mathrm{d}$ $\mathrm{TiO}_{2} \mathrm{NPs}$ )

The reduced Cd-doping mesoporous $\mathrm{TiO}_{2} \quad \mathrm{NPs}$ and 


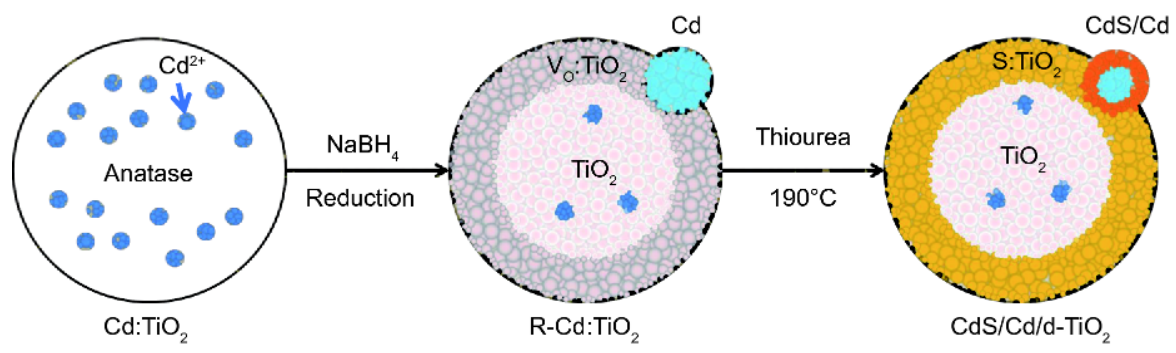

Scheme 1 The synthesis route of $\mathrm{CdS} / \mathrm{Cd} / \mathrm{d}-\mathrm{TiO}_{2}$ core/shell type heterostructure composite.

thiourea were mixed with a certain molar ratio, and then dissolved in $30 \mathrm{~mL}$ hydrazine hydrate under constantly magnetic stirring for $20 \mathrm{~min}$ at room temperature. Afterward the solution was sealed into a $20-\mathrm{mL}$ Teflon lined stainless autoclave and heated to $180^{\circ} \mathrm{C}$ in an electric oven for $24 \mathrm{~h}$, and then naturally cooled to room temperature. The as-prepared precipitate was collected by centrifugation at 5,000 rpm for $15 \mathrm{~min}$, washed with deionized water and ethanol for three times, respectively. Finally, the precipitate was dried in a $70^{\circ} \mathrm{C}$ electronic oven over $12 \mathrm{~h}$. S doped mesoporous $\mathrm{TiO}_{2} \mathrm{NPs}\left(\mathrm{S}: \mathrm{TiO}_{2}\right.$ NPs) were also prepared in a similar procedure except for that the reduced mesoporous $\mathrm{TiO}_{2} \mathrm{NPs}$ were used instead of the reduced Cd-doping mesoporous $\mathrm{TiO}_{2} \mathrm{NPs}$.

\section{Photocatalytic activity measurements}

The photocatalytic activities of samples were evaluated by photocatalytic $\mathrm{H}_{2}$ generation. A photocatalyst $(50 \mathrm{mg})$ without loading noble metal was sealed into $130 \mathrm{~mL}$ aqueous solution of $0.35 \mathrm{~mol} \mathrm{~L}^{-1} \mathrm{Na}_{2} \mathrm{SO}_{3}$ and $0.35 \mathrm{~mol} \mathrm{~L}^{-1}$ $\mathrm{Na}_{2} \mathrm{~S}$ in the cell with a closed gas circulation system and then magnetically stirred during the whole photocatalytic testing. The visible light source was a $300-\mathrm{W}$ Xe lamp (Beijing Perfectlight Technology Co. Ltd) with an optical filter (UVIRCUT-400, Newport) to cut off the short wavelength part $(<400 \mathrm{~nm})$. An AM 1.5 simulated solar power system (Newport) was used as natural light irradiation source. The evolved gases were detected in situ by using an online gas chromatograph (SRI 8610C) equipped with a thermal conductivity detector (TCD).

\section{Characterizations}

The crystalline structure was recorded by using an X-ray diffractometer (XRD) (Bruker AXS D8 Focus), using $\mathrm{Cu}$ Ka radiation $(\lambda=1.54056 \AA ; 40 \mathrm{kV}, 40 \mathrm{~mA})$. Transmission electron microscopy (TEM) images were taken using an FEI Tecnai G2 operated at $200 \mathrm{kV}$. Scanning electron microscopy (SEM) images were measured on a JEOL JSM 4800F. The UV-vis absorption spectra were recorded on a
UV-3101PC UV-vis-NIR scanning spectrophotometer (Shimadzu). X-ray photoelectron spectra (XPS) were obtained on a Thermo Scientific ESCALAB 250 Multitechnique Surface Analysis. The electron paramagnetic resonance (EPR) spectra were recorded at $100 \mathrm{~K}$ on a Bruker A-200 EPR spectrometer. The specific surface area was calculated using the Brunauer-Emmett-Teller (BET) method from the nitrogen absorption data measured on a Micromeritics ASAP2010 volumetric absorption analyzer at $77 \mathrm{~K}$. The steady-state photoluminescence (PL) spectra measurement was obtained by Horiba Jobin Yvon Fluorolog-3 spectrophotometer with a $150 \mathrm{~W}$ ozone-free xenon arc-lamp as the continuous excitation source.

\section{RESULTS AND DISCUSSION}

The preparation process of $\mathrm{CdS} / \mathrm{Cd} / \mathrm{d}-\mathrm{TiO}_{2}$ involves three steps: the formation of $\mathrm{Cd}_{\mathrm{TiO}}$, reduction and vulcanization, as shown in Scheme 1. Cd: $\mathrm{TiO}_{2} \mathrm{NPs}$ are synthesized by adding $\mathrm{Cd}^{2+}$ into $\mathrm{TiO}_{2}$ sol-gel precursor in the presence of $\mathrm{F} 127$ and then calcined at $450^{\circ} \mathrm{C}$. The morphology of $\mathrm{Cd}: \mathrm{TiO}_{2}$ is spherical NPs with a size less than $10 \mathrm{~nm}$ as shown in Fig. 1a inset. XRD patterns confirm that both $\mathrm{TiO}_{2}$ and $\mathrm{Cd}: \mathrm{TiO}_{2}$ are anatase phase (Fig. S1). No characteristic peak of $\mathrm{CdO}$ was observed in the XRD patterns even $10 \mathrm{~mol} \% \mathrm{Cd}^{2+}$ was added into $\mathrm{TiO}_{2}$ sol-gel precursor. The diffraction peak at $25^{\circ}$, attributed to anatase $\mathrm{TiO}_{2}$ (101), turns weak and broad. According to the Scherrer equation $D=K \gamma / B \cos \theta$, where, $D$ is the size of crystalline domain, $K$ is the shape factor with a typical value of $0.9, \gamma$ is the $\mathrm{X}$-ray wavelength, $B$ is the line broadening at half maximum intensity (FWHM), $\theta$ is the Bragg angle, the size of $\mathrm{Cd}: \mathrm{TiO}_{2}$ NPs gradually decreases with the increase in the amount of $\mathrm{Cd}(\mathrm{OAc})_{2}$. XPS was employed to probe the element composition and valence state of $\mathrm{Cd}_{\mathrm{TiO}}$. Fig. S2 shows $\mathrm{Cd} 3 \mathrm{~d}, \mathrm{Ti} 2 \mathrm{p}$ and $\mathrm{O} 2 \mathrm{p}$ peaks at 405, 458 and $532 \mathrm{eV}$, respectively, which confirm the presence of Cd. High resolution XPS spectra of Cd 3d exhibit two peaks at 405.6 and $412.3 \mathrm{eV}$ indicating the $\mathrm{Cd}$ is in $\mathrm{Cd}^{2+}$ state. Element mapping images (Fig. S3) show 

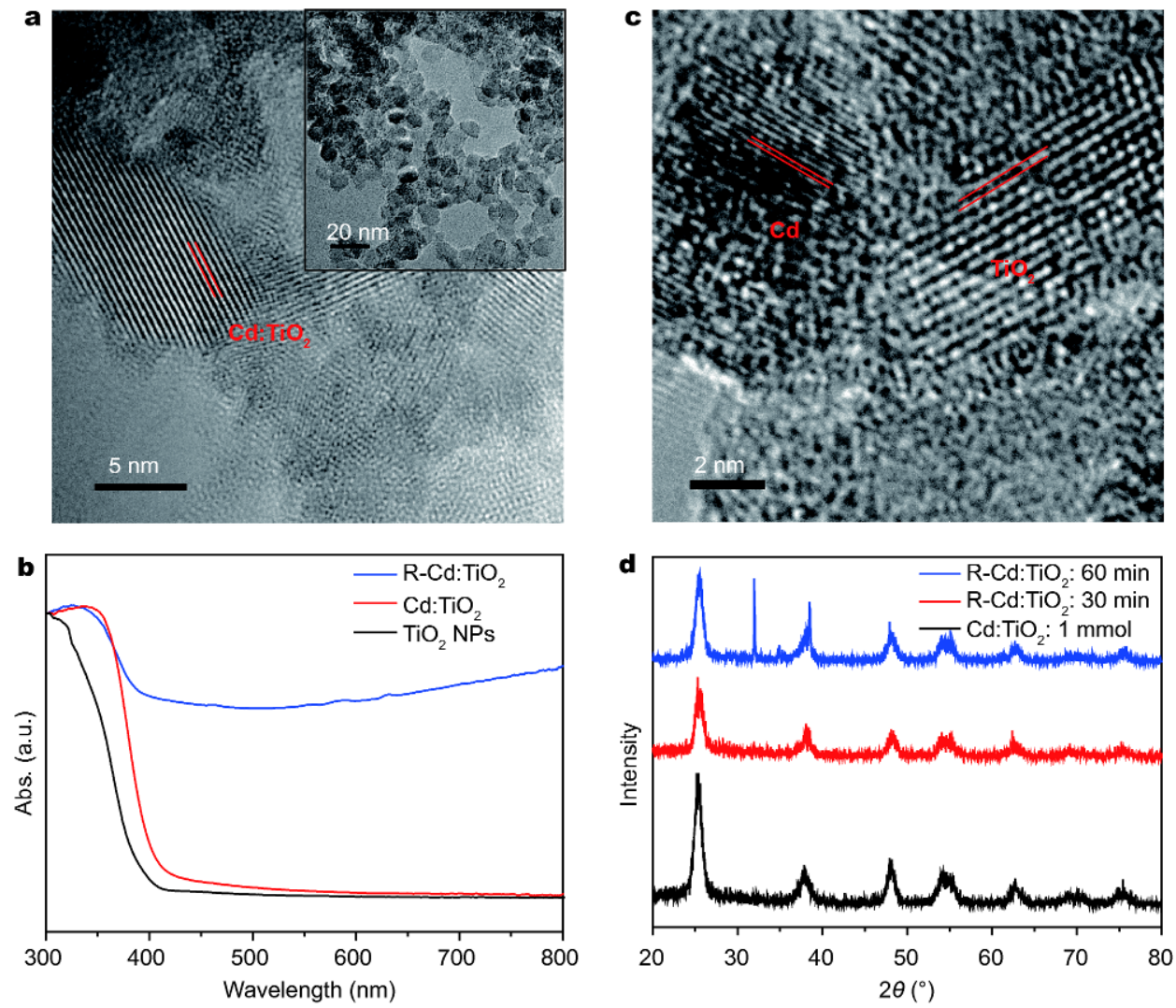

Figure 1 Characterization of $\mathrm{Cd}: \mathrm{TiO}_{2}$ and reduced $\mathrm{Cd}: \mathrm{TiO}_{2}$. (a) HR-TEM graph of $\mathrm{Cd}: \mathrm{TiO}_{2}$ (inset is a low magnitude TEM image of Cd:TiO $\mathrm{T}_{2}$ ). (b) UV-vis spectra of $\mathrm{TiO}_{2} \mathrm{NPs}, \mathrm{Cd}: \mathrm{TiO}_{2}$ and $\mathrm{Cd}: \mathrm{TiO}_{2}$ after $\mathrm{NaBH}_{4}$ treatment for 30 min (R-Cd:TiO$)_{2}$ ). (c) HR-TEM of R-Cd:TiO $\mathrm{NPs}_{2}$ (d) XRD patterns of $\mathrm{Cd}: \mathrm{TiO}_{2}$, R-Cd:TiO${ }_{2}$ treated for 30 and $60 \mathrm{~min}$.

that $\mathrm{Cd}, \mathrm{Ti}$ and $\mathrm{O}$ are uniformly dispersed in the whole sample. High resolution TEM (HR-TEM) photography of Cd: $\mathrm{TiO}_{2}$ (Fig. 1a) exhibits clear lattice fringes of $0.35 \mathrm{~nm}$ corresponding to the (110) of anatase $\mathrm{TiO}_{2}$ crystal. It further confirms that the as-prepared $\mathrm{Cd}_{\mathrm{TiO}}$ has crystalline anatase phase. After doping with $\mathrm{Cd}$, the optical band edge has a clear red-shift from 387 to $409 \mathrm{~nm}$ (Fig. 1b). That moves the band gap of $\mathrm{Cd}_{\mathrm{TiO}}$ to $3.0 \mathrm{eV}$ vs. $3.2 \mathrm{eV}$ for $\mathrm{TiO}_{2}$. The doping concentration of $\mathrm{Cd}$ can be tuned by tuning the amount of $\mathrm{Cd}(\mathrm{OAc})_{2}$.

Furthermore, $\mathrm{Cd}: \mathrm{TiO}_{2} \mathrm{NPs}$ were mixed with $\mathrm{NaBH}_{4}$ by grounding and then the mixture was placed at $350^{\circ} \mathrm{C}$ for 30 or $60 \mathrm{~min}$ in flowing argon at atmospheric pressure. The surface (shell) of the $\mathrm{Cd}: \mathrm{TiO}_{2}$ NPs was reduced during the $\mathrm{NaBH}_{4}$ decomposition to form metal Cd NPs and the reduced $\mathrm{TiO}_{2}$ with oxygen vacancies (denoted as $\mathrm{R}-\mathrm{Cd}: \mathrm{TiO}_{2}$ ) as shown in Scheme 1. Fig. 1c displays the HR-TEM images of R-Cd:TiO ${ }_{2}$. It clearly illustrates that the metal Cd NPs with $0.14 \mathrm{~nm}$ of lattice fringe located besides the $\mathrm{TiO}_{2}$ NPs with $0.35 \mathrm{~nm}$ of lattice fringe. Amorphous $\mathrm{TiO}_{2}$ shell is observed surrounding the R-Cd:
$\mathrm{TiO}_{2}$ NPs (Fig. 1c). After $\mathrm{NaBH}_{4}$ treatment, the optical band edge of $\mathrm{R}-\mathrm{Cd}: \mathrm{TiO}_{2}$ further shifts towards visible light $(\sim 460 \mathrm{~nm})$ and another broad absorption band appears in the visible light region due to the introducing of oxygen vacancies (Fig. 1b), which matches well with our previous reported result [36]. All these results confirm that the $\mathrm{NaBH}_{4}$ treatment not only transferred the surface $\mathrm{Cd}^{2+}$ into Cd metal NP, but also promoted the formation of the reduced $\mathrm{TiO}_{2}$ NPs shell with surface oxygen vacancies. Fig. 1d exhibits the XRD patterns of $\mathrm{Cd}: \mathrm{TiO}_{2}$ and $\mathrm{R}-\mathrm{Cd}: \mathrm{TiO}_{2}$ with different treatment time. After $30 \mathrm{~min}$ treatment, there is a very weak peak appear at $32^{\circ}$, which is characteristic diffraction peak of metal Cd NPs. The peak turns stronger when the treatment time prolongs to 60 min. It indicates the $\mathrm{NaBH}_{4}$ treatment could reduce $\mathrm{Cd}^{2+}$ in $\mathrm{Cd}: \mathrm{TiO}_{2}$ into Cd metal NPs. Particle size of R-Cd: $\mathrm{TiO}_{2}$ calculated by Scherrer formula decreases from 13.24 to $12.04 \mathrm{~nm}$, which is well consistent with that of crystal size observed by TEM images.

Furthermore, R-Cd: $\mathrm{TiO}_{2}$ was treated with thiourea under hydrothermal condition, which has two purposes: 

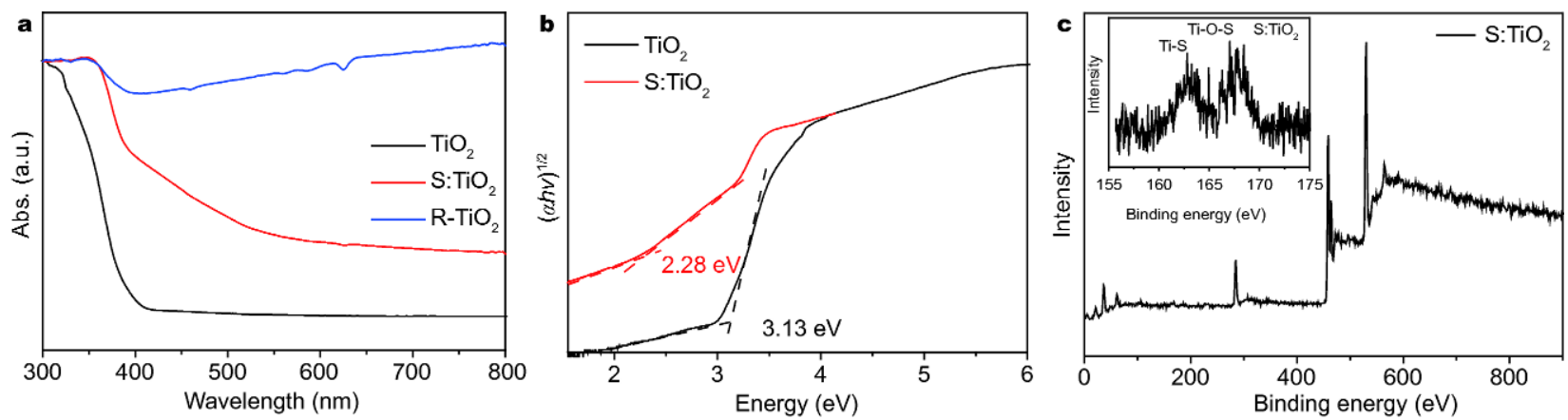

Figure 2 Optical properties and XRD of $\mathrm{TiO}_{2}$ and S:TiO${ }_{2}$. (a) Diffuse reflectance UV-vis spectra of $\mathrm{TiO}_{2}, \mathrm{R}_{\mathrm{TiO}} \mathrm{Ti}_{2}$ and $\mathrm{S}: \mathrm{TiO}_{2}$ represented as d-TiO $(\mathrm{S}$ : $\mathrm{TiO}_{2} / \mathrm{TiO}_{2}$ ). (b) Transformed Kubelka-Munk function $v$ s. photon energy plot of $\mathrm{TiO}_{2}$ and $\mathrm{S}: \mathrm{TiO}_{2}$. (c) Full XPS spectra of S:TiO${ }_{2}$ (inset is the high resolution S 2p XPS spectra).

(i) $\mathrm{S}^{2-}$ refills back to oxygen vacancies of $\mathrm{R}-\mathrm{Cd}: \mathrm{TiO}_{2}$ to form core shell structure of $\mathrm{S}: \mathrm{TiO}_{2} / \mathrm{TiO}_{2}$; (ii) metal Cd NPs in the out-shell are vulcanized and form CdS or CdS/ $\mathrm{Cd}$ nanostructure depending on the amount of thiourea. In order to confirm that $\mathrm{S}^{2-}$ can refill the site of oxygen vacancy, $\mathrm{R}-\mathrm{TiO}_{2}$ was prepared by $\mathrm{NaBH}_{4}$ treatment of $\mathrm{TiO}_{2}$ as the same route as $\mathrm{R}-\mathrm{Cd}: \mathrm{TiO}_{2}$ then treated with thiourea. Fig. 2a shows the $\mathrm{UV}$-vis spectra of $\mathrm{TiO}_{2}$, $\mathrm{R}$ $\mathrm{TiO}_{2}$ and $\mathrm{S}: \mathrm{TiO}_{2}$ NPs. After $\mathrm{NaBH}_{4}$ treatment, $\mathrm{TiO}_{2}$ is reduced to form $\mathrm{R}-\mathrm{TiO}_{2}$ with surface oxygen vacancies. Its UV-vis spectrum shows strong broad light absorption in the visible light region. After thiourea treatment, a band tail in the range of 410-520 $\mathrm{nm}$ appears in the UVvis spectrum. The band tail can be attributed to the formation of $\mathrm{S}$ doped $\mathrm{TiO}_{2}\left(\mathrm{~S}: \mathrm{TiO}_{2}\right)$ which exhibits narrower band gap of $2.28 \mathrm{eV}$ from transformed Kubelka-Munk function $v s$. photon energy plot (Fig. $2 \mathrm{~b}$ ). This result also confirms that $\mathrm{S}: \mathrm{TiO}_{2}$ has broad absorption in the visible light region. In addition, the absorption decreasing in the IR region for the $\mathrm{S}: \mathrm{TiO}_{2}$ demonstrates the decrease of oxygen vacancies. Furthermore, XPS spectra of $\mathrm{S}: \mathrm{TiO}_{2}$ (Fig. 2c) also display a peak at $\sim 165 \mathrm{eV}$, which corresponds to the $S 2 \mathrm{p}$ signal, which confirms the presence of $\mathrm{S}^{2-}$ in the thiourea treated $\mathrm{TiO}_{2}$ sample. The valence band XPS spectra of $\mathrm{TiO}_{2}$ and $\mathrm{S}: \mathrm{TiO}_{2}$ ( Fig. S4) show that the band edge of $\mathrm{S}: \mathrm{TiO}_{2}$ shifts to low binding energy, indicating the valence band of $\mathrm{S}: \mathrm{TiO}_{2} / \mathrm{TiO}_{2}$ shift upwards due to $S 2 p$ orbital has lower binding energy [37].

Fig. 3a displays the XRD patterns of $\mathrm{R}-\mathrm{Cd}: \mathrm{TiO}_{2}$ hydrothermally treated with different amounts of thiourea. When the molar ratio of $\mathrm{Cd} /$ thiourea is less than $1 / 1$, a new series of XRD peaks are observed at $26.6^{\circ}, 28.3^{\circ}$, $43.8^{\circ}$, and $51.9^{\circ}$, which can be assigned to wurtzite type CdS (PDF\# 77-2306). The diffraction peak at $32^{\circ}$ still exists and peak intensity decreases, indicating that metal
Cd NPs and CdS co-exist in the sample. When excess amount of thiourea $(\mathrm{Cd} / \mathrm{S}=1 / 10)$ was added into the reaction, the characteristic peak of metal Cd disappears and only CdS characteristic diffraction peaks are observed, indicating that the metal $\mathrm{Cd}$ can be fully converted into $\mathrm{CdS}$ in the hydrothermal reaction.

HR-TEM image (Fig. 3b) illustrates three kinds of NPs with lattice fringe of $0.35,0.14$ and $0.32 \mathrm{~nm}$, respectively, corresponding to (101) of $\mathrm{TiO}_{2},(004)$ of $\mathrm{Cd}$ and (101) of $\mathrm{CdS}$, respectively. Metal Cd was sandwiched between CdS and $\mathrm{TiO}_{2}$ NP. Fig. $3 \mathrm{c}$ shows the UV-vis spectra of thiourea treated $\mathrm{R}-\mathrm{Cd}: \mathrm{TiO}_{2}$ with different amounts of thiourea. With the formation of CdS, another absorption band in the 400-550 $\mathrm{nm}$ region appears. With pure CdS as a reference, this band can be assigned to the absorption of CdS in the composite. It should be noted that the absorption band shape of $\mathrm{Cd} / \mathrm{S}=5 / 1$ is closer to that of $\mathrm{S}$ : $\mathrm{TiO}_{2} / \mathrm{TiO}_{2}$ (Figs $2 \mathrm{a}$ and $3 \mathrm{c}$ ) than other samples. It may imply that the $\mathrm{S}^{2-}$ produced from thiourea refills oxygen vacancies to form $\mathrm{S}: \mathrm{TiO}_{2}$ prior to reacting with $\mathrm{Cd}$ to produce CdS. Excess amount of thiourea results in the formation of $\mathrm{CdS} / \mathrm{d}-\mathrm{TiO}_{2}$ heterojunction due to that the metal Cd is fully transferred into CdS. Fig. $3 \mathrm{~d}$ shows the high resolution Cd XPS spectra of $\mathrm{Cd}: \mathrm{TiO}_{2}, \mathrm{R}-\mathrm{Cd}: \mathrm{TiO}_{2}$ and $\mathrm{CdS} / \mathrm{Cd} / \mathrm{d}-\mathrm{TiO}_{2}$. Two peaks at 405.6 and $412.3 \mathrm{eV}$ are contributed from Cd $3 \mathrm{~d}_{5 / 2}$ and $3 \mathrm{~d}_{3 / 2}$, respectively. In the case of $\mathrm{R}-\mathrm{Cd}: \mathrm{TiO}_{2}$, these peaks shift toward low binding energy 404.8 and $411.5 \mathrm{eV}$ due to the formation of metal $\mathrm{Cd}$. After thiourea treatment, these peaks shift back to high binding energy 405.1 and $411.9 \mathrm{eV}$, respectively. Those results indicate that partial $\mathrm{Cd}^{0}$ was converted into $\mathrm{Cd}^{2+}$ in the treatment, which matches with our results and explanation. We also checked the EPR spectra to understand the changes of the oxygen vacancy in the treatment. EPR spectra (Fig. S5) clearly show that the $\mathrm{TiO}_{2}$ and $\mathrm{CdS}$ 

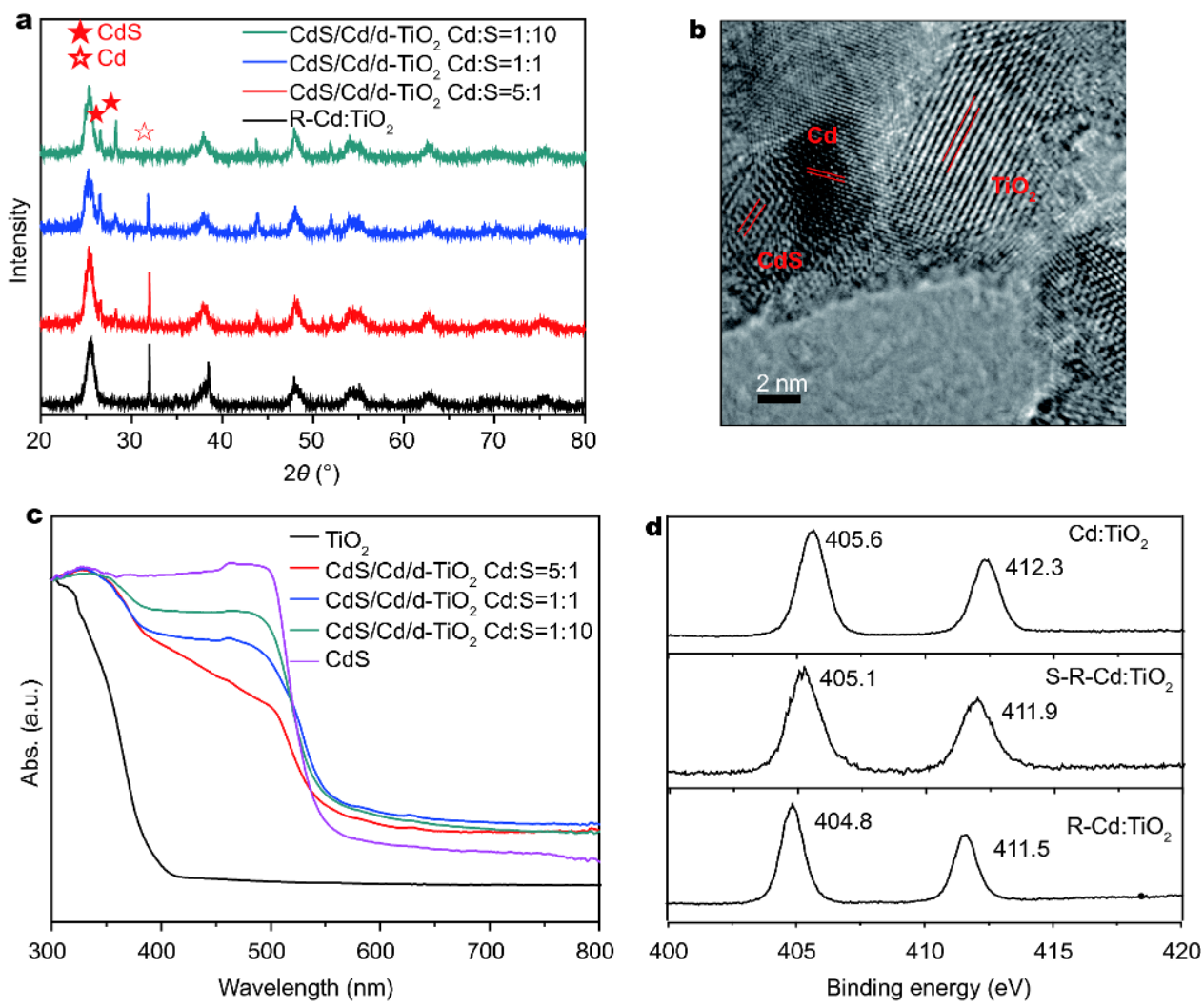

Figure 3 (a) XRD patterns of R-Cd:TiO ${ }_{2}$ and hydrothermally treated R-Cd:TiO ${ }_{2}$ with different amounts of thiourea. (b) HR-TEM image of CdS/Cd/ d- $-\mathrm{TiO}_{2}$. (c) UV-vis spectra of $\mathrm{TiO}_{2}, \mathrm{CdS}$, and $\mathrm{CdS} / \mathrm{Cd} / \mathrm{d}-\mathrm{TiO}_{2}$ obtained with different amounts of thiourea treatment. (d) High resolution Cd XPS of the as-prepared Cd:TiO ${ }_{2}, \mathrm{R}-\mathrm{Cd}: \mathrm{TiO}_{2}$ and $\mathrm{CdS} / \mathrm{Cd} / \mathrm{d}-\mathrm{TiO}_{2} \mathrm{NPs}$.

did not display vacancy signal at 3,418 Gauss. The samples treated with $\mathrm{NaBH}_{4}$ exhibit strong EPR signal, which confirms the presence of oxygen vacancies. Although the EPR signal decreases in the sample treated with thiourea $\left(\mathrm{CdS} / \mathrm{Cd} / \mathrm{d}-\mathrm{TiO}_{2}\right)$, the oxygen vacancies still exist in the sample inside.

In general, solid state Z-scheme such as $\mathrm{CdS} / \mathrm{Au} / \mathrm{TiO}_{2}$ works well in the UV light region, because the excited charge can only be produced in the UV light region for at least one component such as the $\mathrm{TiO}_{2}$ photocatalyst. It is prerequisite to have both PSI and PSII photocatalysts respond to visible light in order to constructing Z-scheme nanostructure working in visible light region. Here the synthesized heteronanostructures were used as PSII photocatalysts. Photocatalytic $\mathrm{H}_{2}$ production activities were evaluated under both AM 1.5 and visible light $(\lambda>$ $400 \mathrm{~nm}$ ) irradiation by using $\mathrm{Na}_{2} \mathrm{SO}_{3}-\mathrm{Na}_{2} \mathrm{~S}$ buffer solution as the sacrificial reagent to quench the photo-induced holes. Firstly, photocatalytic $\mathrm{H}_{2}$ evolution rates of control samples like $\mathrm{TiO}_{2}, \mathrm{R}-\mathrm{TiO}_{2}$ and $\mathrm{R}-\mathrm{Cd}: \mathrm{TiO}_{2}$ without loading cocatalyst under AM 1.5 (1 Sun) irradiation were studied and the results were listed in Fig. S6. The as-prepared $\mathrm{TiO}_{2}$ NPs showed the $\mathrm{H}_{2}$ evolution rate of about $24 \mu \mathrm{mol} \mathrm{h}{ }^{-1}$ for $50 \mathrm{mg}$ of photocatalyst. After $\mathrm{NaBH}_{4}$ treatment, oxygen vacancies were introduced onto the surface of $\mathrm{TiO}_{2} \mathrm{NPs}\left(\mathrm{R}-\mathrm{TiO}_{2}\right)$. The photocatalytic activity of $\mathrm{R}-\mathrm{TiO}_{2}$ was improved to $50.3 \mu \mathrm{mol} \mathrm{h}{ }^{-1}$, which doubled the $\mathrm{H}_{2}$ evolution rate of the original $\mathrm{TiO}_{2} \mathrm{NPs}$. The $\mathrm{H}_{2}$ evolution rate of $\mathrm{Cd}: \mathrm{TiO}_{2}$ sample exhibited similar improvement as that of $\mathrm{R}-\mathrm{TiO}_{2}$. These results agree well with our previous reports [36]. Further sulfurization of R$\mathrm{TiO}_{2}$ led to the formation of $\mathrm{S}: \mathrm{TiO}_{2} / \mathrm{TiO}_{2}$, whose photocatalytic activity was close to that of $\mathrm{R}-\mathrm{TiO}_{2}$ without obvious improvement. Fig. S7 illustrates the visible light photocatalytic activities of these samples. The study confirms that $\mathrm{TiO}_{2}$ has almost negligible photocatalytic activity due to its large band gap. Although $\mathrm{R}-\mathrm{TiO}_{2}$ and $\mathrm{S}$ : $\mathrm{TiO}_{2} / \mathrm{TiO}_{2}$ (Fig. 4b) show clear visible light absorption, their photocatalytic activities are relatively weak in the visible light region [36].

The $\mathrm{H}_{2}$ production rates of $\mathrm{S}: \mathrm{TiO}_{2} / \mathrm{TiO}_{2}, \mathrm{CdS}, \mathrm{CdS} / \mathrm{Cd} /$ $\mathrm{d}-\mathrm{TiO}_{2}$ and $\mathrm{CdS} / \mathrm{d}-\mathrm{TiO}_{2}$ under the AM 1.5 irradiation (1 

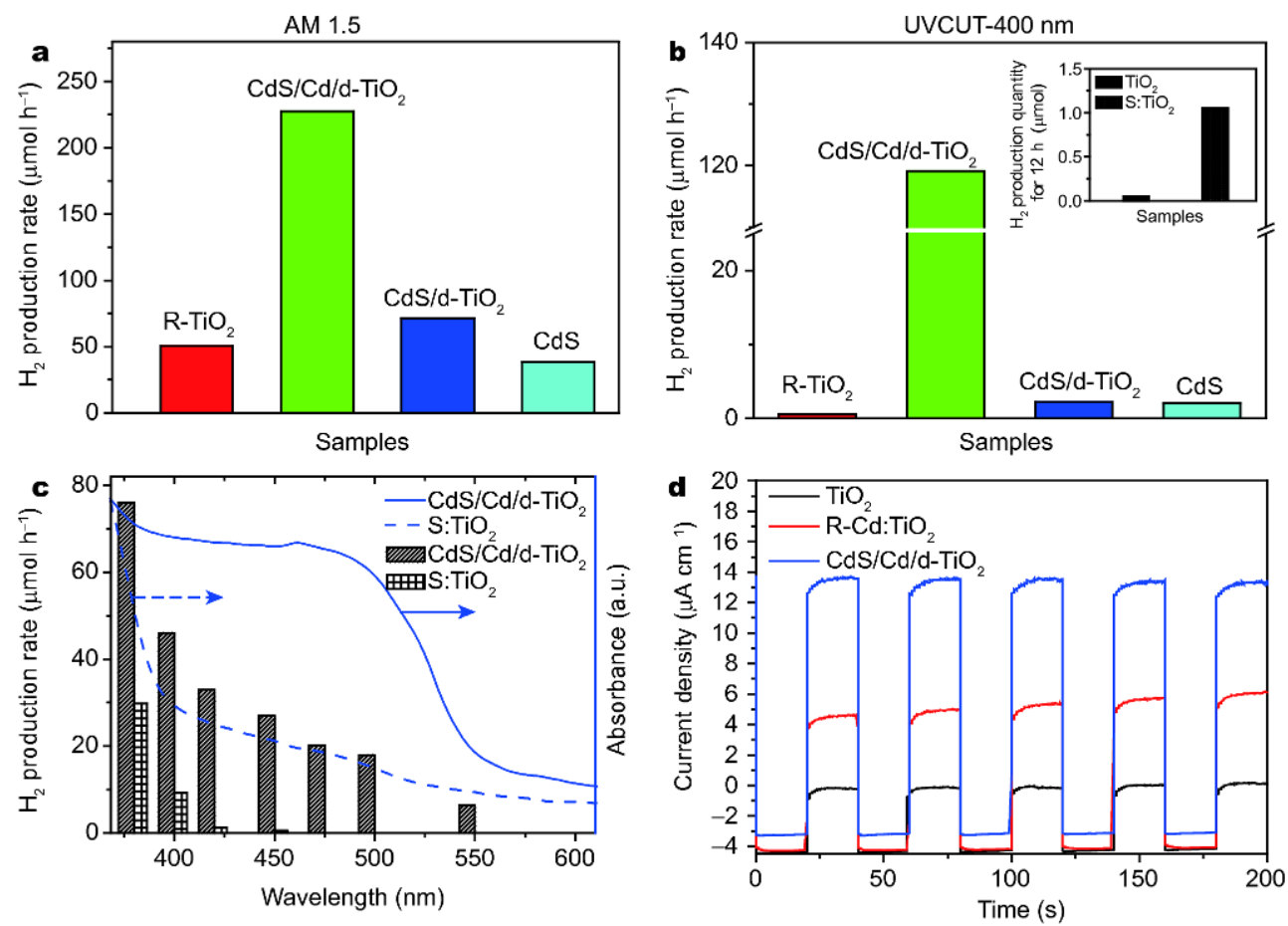

Figure $4 \mathrm{H}_{2}$ evolution rate of $\mathrm{S}: \mathrm{TiO}_{2}, \mathrm{CdS}, \mathrm{CdS} / \mathrm{Cd} / \mathrm{d}-\mathrm{TiO}_{2}$ and $\mathrm{CdS} / \mathrm{TiO}_{2}$ under $\mathrm{AM} 1.5$ (a) and visible light $(\lambda>400 \mathrm{~nm})(\mathrm{b})$ irradiation in the $0.35 \mathrm{~mol} \mathrm{~L} \mathrm{Na}_{2} \mathrm{SO}_{3}-0.35 \mathrm{~mol} \mathrm{~L}^{-1} \quad \mathrm{Na}_{2} \mathrm{~S}$ aqueous solution. The inset of (b) is the $\mathrm{H}_{2}$ production rate of $\mathrm{TiO}_{2}$ and $\mathrm{S}: \mathrm{TiO}_{2}$ under visible light. (c) $\mathrm{H}_{2}$ production dependence of $\mathrm{CdS} / \mathrm{Cd} / \mathrm{d}-\mathrm{TiO}_{2}$ and $\mathrm{CdS} / \mathrm{TiO}_{2}$ on the wavelength under different band pass, the curves are the UV-vis spectra of S:TiO${ }_{2}$ (dash) and $\mathrm{CdS} / \mathrm{Cd} / \mathrm{d}-\mathrm{TiO}_{2}$ (solid). (d) Transient photocurrent responses of $\mathrm{TiO}_{2}, \mathrm{R}-\mathrm{Cd}: \mathrm{TiO}_{2}$ and $\mathrm{CdS} / \mathrm{Cd} / \mathrm{d}-\mathrm{TiO}_{2}$.

Sun) are summarized in the Fig. 4a. The $\mathrm{H}_{2}$ evolution rates of $\mathrm{S}: \mathrm{TiO}_{2} / \mathrm{TiO}_{2}$ and $\mathrm{CdS}$ were 50.3 and $38.4 \mathrm{~mol} \mathrm{~h}^{-1}$, respectively, for $50 \mathrm{mg}$ photocatalyst without Pt cocatalyst. R-Cd: $\mathrm{TiO}_{2}$ displayed slightly enhanced photocatalytic activity $\left(57 \mu \mathrm{mol} \mathrm{h}{ }^{-1}\right)$ in comparison with $\mathrm{R}-\mathrm{TiO}_{2}$. This improvement could be caused by the formation of metal Cd NPs, which promoted the charge separation and functioned as a cocatalyst. $\mathrm{CdS} / \mathrm{Cd} /$ d- $\mathrm{TiO}_{2}$ composite treated under $\mathrm{Cd}: \mathrm{S}=1: 1$ condition exhibited much higher photocatalytic $\mathrm{H}_{2}$ evolution rate $\left(227 \mu \mathrm{mol} \mathrm{h}^{-1}\right)$ than that of other samples studied here, which is about $4-5$ times better than that of $\mathrm{S}: \mathrm{TiO}_{2}$ and CdS. With excess amount of thiourea used in the sulfuration reaction ( $\mathrm{Cd}: \mathrm{S}=1: 10)$, metal $\mathrm{Cd}$ was fully converted into $\mathrm{CdS}$ leading to the formation of $\mathrm{CdS} / \mathrm{d}-\mathrm{TiO}_{2}$ heterojunction, no longer a $\mathrm{Z}$-scheme, in which photogenerated electrons transferred from CdS to $\mathrm{TiO}_{2}$. In comparison with other single component CdS or $\mathrm{d}-\mathrm{TiO}_{2}$, heterojunction $\mathrm{CdS} / \mathrm{d}-\mathrm{TiO}_{2}$ showed improved photocatalytic activities because the heterojunction structural feature can improve the charge separation. The photocatalytic activities of $\mathrm{CdS} / \mathrm{d}-\mathrm{TiO}_{2}$ is two-fold higher than that of $\mathrm{CdS}$ or $\mathrm{S}: \mathrm{TiO}_{2} / \mathrm{TiO}_{2}$. Our studies show that $\mathrm{CdS} /$
$\mathrm{Cd} / \mathrm{d}-\mathrm{TiO}_{2}$ possessed even better photocatalytic activity than that of heterojunction due to the existence of metal $\mathrm{Cd}$, although the samples have quite similar absorption capability. Fig. $4 \mathrm{~b}$ illustrates the photocatalytic $\mathrm{H}_{2}$ production rates of $\mathrm{S}: \mathrm{TiO}_{2} / \mathrm{TiO}_{2}, \mathrm{CdS}, \mathrm{CdS} / \mathrm{Cd} / \mathrm{d}-\mathrm{TiO}_{2}$ and $\mathrm{CdS} / \mathrm{d}-\mathrm{TiO}_{2}$ under visible light irradiation. Both $\mathrm{S}: \mathrm{TiO}_{2} /$ $\mathrm{TiO}_{2}$ and CdS exhibit relatively weak photocatalytic activity of 0.57 and $2.03 \mu \mathrm{mol} \mathrm{h}^{-1}$ without loading Pt cocatalyst. The $\mathrm{CdS} / \mathrm{d}-\mathrm{TiO}_{2}$ heterojunction with less than $10 \%$ of CdS displays $2.17 \mu \mathrm{mol} \mathrm{h}^{-1}$ of $\mathrm{H}_{2}$ production rate for $50 \mathrm{mg}$ photocatalyst. The $\mathrm{CdS} / \mathrm{Cd} / \mathrm{d}-\mathrm{TiO}_{2}$ exhibits significant enhanced photocatalytic activity. The $\mathrm{H}_{2}$ production rate reaches $119 \mu \mathrm{mol} \mathrm{h}^{-1}$, which is near 200 and $\sim 60$ times higher than $\mathrm{d}-\mathrm{TiO}_{2}$ and $\mathrm{CdS} / \mathrm{d}-\mathrm{TiO}_{2}$ due to the existence of metal Cd NPs. These results indicate that metal Cd greatly promote the charge separation and the photocatalytic performance due to the formation of $\mathrm{Z}$ scheme type photocatalytic system.

To better understand the significant enhancement, the dependence of $\mathrm{H}_{2}$ production rate on the irradiation wavelength with $\sim 20 \mathrm{~nm}$ band-width is shown in Fig. $4 \mathrm{c}$. Although $\mathrm{S}: \mathrm{TiO}_{2} / \mathrm{TiO}_{2}$ has absorption in the visible light region, its $\mathrm{H}_{2}$ production rate is quite low and almost zero 
after $450 \mathrm{~nm}$. The $\mathrm{H}_{2}$ production rates studied with different wavelengths also decreased dramatically in the visible light region for $\mathrm{CdS} / \mathrm{d}-\mathrm{TiO}_{2}$, due to the content of CdS is far below $10 \mathrm{wt} \%$ (Fig. S8). In the case of CdS/Cd/ $\mathrm{d}-\mathrm{TiO}_{2}$, its absorption curve is close to the absorption curve of CdS in the visible light region. However, the $\mathrm{H}_{2}$ production rate continuously decreases in the visible light region, the trend of $\mathrm{H}_{2}$ production rate for $\mathrm{CdS} / \mathrm{Cd} / \mathrm{d}$ $\mathrm{TiO}_{2}$ matches well with that of $\mathrm{S}: \mathrm{TiO}_{2} / \mathrm{TiO}_{2}$. That implies that the absorption capability of $\mathrm{S}: \mathrm{TiO}_{2} / \mathrm{TiO}_{2}$ is the restriction factor in the $\mathrm{CdS} / \mathrm{Cd} / \mathrm{d}-\mathrm{TiO}_{2}$ photocatalyst. Although both $\mathrm{CdS} / \mathrm{Cd} / \mathrm{d}-\mathrm{TiO}_{2}$ and $\mathrm{CdS} / \mathrm{d}-\mathrm{TiO}_{2}$ have similar light absorption, the $\mathrm{H}_{2}$ production rate of the former is much higher than that of the latter, indicating that the charge separation efficiency of $\mathrm{CdS} / \mathrm{Cd} / \mathrm{d}-\mathrm{TiO}_{2}$ is much higher than that of $\mathrm{CdS} / \mathrm{d}-\mathrm{TiO}_{2}$. This result implies that the formation of Z-scheme structural configuration in the $\mathrm{CdS} / \mathrm{Cd} / \mathrm{d}-\mathrm{TiO}_{2}$ could have played a pivotal role in the enhancement of the material's photocatalytic activity. PL spectra of S: $\mathrm{TiO}_{2} / \mathrm{TiO}_{2}, \mathrm{CdS}, \mathrm{CdS} / \mathrm{Cd} / \mathrm{d}-\mathrm{TiO}_{2}$ and CdS/ $\mathrm{d}-\mathrm{TiO}_{2}$ are shown in Fig. S9. The PL emission was quenched by the formation of $\mathrm{CdS} / \mathrm{Cd} / \mathrm{d}-\mathrm{TiO}_{2}$ and $\mathrm{CdS} /$ $\mathrm{d}-\mathrm{TiO}_{2}$, indicating the charge separation efficiency in the heterostructure is better than that in single component. In addition, only CdS emission was quenched in the CdS/d$\mathrm{TiO}_{2}$ heterojunction. Both emissions from $\mathrm{TiO}_{2}$ and $\mathrm{CdS}$ are quenched in the case of $\mathrm{CdS} / \mathrm{Cd} / \mathrm{d}-\mathrm{TiO}_{2}$ indicating that it has better charge separation efficiency than that of $\mathrm{CdS} / \mathrm{d}-\mathrm{TiO}_{2}$. Furthermore, the photoelectrochemical cell was constructed to investigate the transient photocurrent density (Fig. 4d). Comparing with $\mathrm{TiO}_{2}$ and R-Cd:TiO${ }_{2}$, the $\mathrm{CdS} / \mathrm{Cd} / \mathrm{d}-\mathrm{TiO}_{2}$ exhibits the highest photocurrent density, which matches well with photocatalytic $\mathrm{H}_{2}$ production results.

According to the above results, we propose a $\mathrm{Z}$-scheme working mechanism for the $\mathrm{CdS} / \mathrm{Cd} / \mathrm{d}-\mathrm{TiO}_{2}$ composite photocatalyst (Fig. 5). CdS/Cd/d- $\mathrm{TiO}_{2}$ exhibits broad visible light absorption due to coexistence of $\mathrm{d}-\mathrm{TiO}_{2}$ and CdS. Under visible light irradiation, both $\mathrm{d}-\mathrm{TiO}_{2}$ and $\mathrm{CdS}$ can produce excited charges. The excited electron from $\mathrm{d}-\mathrm{TiO}_{2}$ can recombine with the hole from CdS through the metal $\mathrm{Cd}$. The more reductive electron from $\mathrm{CdS}$ and oxidative hole from $\mathrm{d}-\mathrm{TiO}_{2}$ were left in the composite photocatalyst for oxidation and reduction reactions. This greatly enhanced the charge separation efficiency of the system. The composite exhibits much better photocatalytic activity compared with any single component.

\section{CONCLUSIONS}

In summary, starting from $\mathrm{Cd}: \mathrm{TiO}_{2}$ through reduction

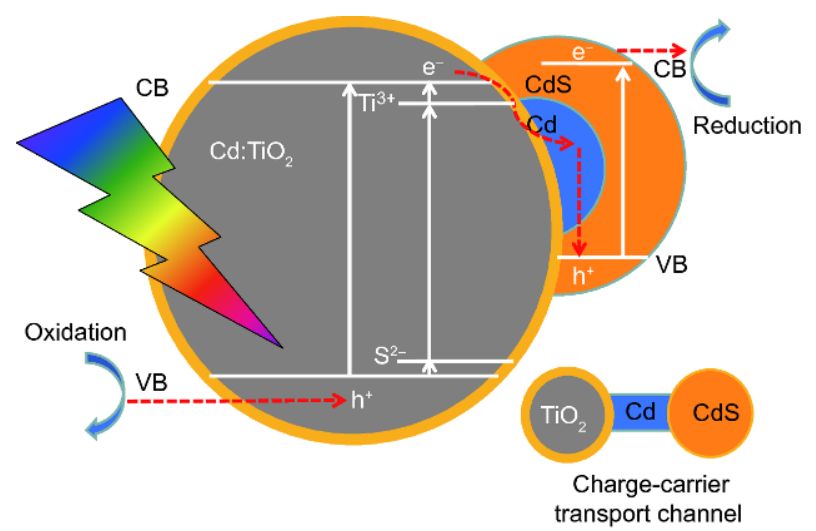

Figure 5 The proposed work mechanism of $\mathrm{CdS} / \mathrm{Cd} / \mathrm{d}-\mathrm{TiO}_{2}$ composites.

and sulfuration, a novel solid state Z-scheme configuration based on $\mathrm{CdS} / \mathrm{Cd} / \mathrm{d}-\mathrm{TiO}_{2}$ composite was obtained. Both $\mathrm{CdS}$ and $\mathrm{d}-\mathrm{TiO}_{2}$ showed the visible light responsive absorption properties. With the formed Cd metal NPs in the system acting as electron transfer mediator, the composite showed impressive photocatalytic activity in the visible light region. Through series systematic studies, the formed heteronanostructured material was thoroughly understood and well characterized. A working mechanism of the formed Z-scheme was proposed. The reported method is innovative and could be easily extended to other materials for the construction of solid state Z-scheme. This could pave the way toward the search for efficient photocatalytic materials in visible light spectrum.

Received 18 October 2017; accepted 27 November 2017; published online 15 December 2017

1 Osterloh FE. Inorganic nanostructures for photoelectrochemical and photocatalytic water splitting. Chem Soc Rev, 2013, 42: 22942320

2 Ran J, Zhang J, Yu J, et al. Earth-abundant cocatalysts for semiconductor-based photocatalytic water splitting. Chem Soc Rev, 2014, 43: 7787-7812

3 Navarro Yerga RM, Alvarez Galván MC, del Valle F, et al. Water splitting on semiconductor catalysts under visible-light irradiation. ChemSusChem, 2009, 2: 471-485

4 Maeda K, Domen K. Photocatalytic water splitting: recent progress and future challenges. J Phys Chem Lett, 2010, 1: 2655-2661

5 Ma XC, Dai Y, Yu L, et al. Energy transfer in plasmonic photocatalytic composites. Light Sci Appl, 2016, 5: e16017

6 Shi R, Cao Y, Bao Y, et al. Self-assembled Au/CdSe nanocrystal clusters for plasmon-mediated photocatalytic hydrogen evolution. Adv Mater, 2017, 29: 1700803

7 Rao PM, Cai L, Liu C, et al. Simultaneously efficient light absorption and charge separation in $\mathrm{WO}_{3} / \mathrm{BiVO}_{4}$ core/shell nanowire photoanode for photoelectrochemical water oxidation. Nano Lett, 2014, 14: 1099-1105 
8 Wang H, Zhang L, Chen Z, et al. Semiconductor heterojunction photocatalysts: design, construction, and photocatalytic performances. Chem Soc Rev, 2014, 43: 5234-5244

9 Moniz SJA, Shevlin SA, Martin DJ, et al. Visible-light driven heterojunction photocatalysts for water splitting-a critical review. Energ Environ Sci, 2015, 8: 731-759

10 Zhang J, Zhang M, Sun RQ, et al. A facile band alignment of polymeric carbon nitride semiconductors to construct isotype heterojunctions. Angew Chem, 2012, 124: 10292-10296

11 Chen S, Qi Y, Hisatomi T, et al. Efficient visible-light-driven Zscheme overall water splitting using a $\mathrm{MgTa}_{2} \mathrm{O}_{6-x} \mathrm{~N}_{y} / \mathrm{TaON}$ heterostructure photocatalyst for $\mathrm{H}_{2}$ evolution. Angew Chem, 2015, 127: $8618-8621$

12 Maeda K. Z-scheme water splitting using two different semiconductor photocatalysts. ACS Catal, 2013, 3: 1486-1503

13 Zhou P, Yu J, Jaroniec M. All-solid-state Z-scheme photocatalytic systems. Adv Mater, 2014, 26: 4920-4935

14 Li H, Tu W, Zhou Y, et al. Z-scheme photocatalytic systems for promoting photocatalytic performance: recent progress and future challenges. Adv Sci, 2016, 3: 1500389

15 Wang X, Liu G, Wang L, et al. ZnO-CdS@Cd heterostructure for effective photocatalytic hydrogen generation. Adv Energ Mater, 2012, 2: 42-46

16 Tada H, Mitsui T, Kiyonaga T, et al. All-solid-state Z-scheme in CdS- $\mathrm{Au}-\mathrm{TiO}_{2}$ three-component nanojunction system. Nat Mater, 2006, 5: 782-786

17 Jin J, Yu J, Guo D, et al. A hierarchical Z-scheme CdS- $\mathrm{WO}_{3}$ photocatalyst with enhanced $\mathrm{CO}_{2}$ reduction activity. Small, 2015, 11: 5262-5271

18 Yu ZB, Xie YP, Liu G, et al. Self-assembled CdS/Au/ZnO heterostructure induced by surface polar charges for efficient photocatalytic hydrogen evolution. J Mater Chem A, 2013, 1: 2773-2776

19 Ye L, Liu J, Gong C, et al. Two different roles of metallic Ag on Ag/ $\mathrm{AgX} / \mathrm{BiOX}(\mathrm{X}=\mathrm{Cl}, \mathrm{Br})$ visible light photocatalysts: surface plasmon resonance and Z-scheme bridge. ACS Catal, 2012, 2: 16771683

20 Zheng D, Pang C, Wang X. The function-led design of Z-scheme photocatalytic systems based on hollow carbon nitride semiconductors. Chem Commun, 2015, 51: 17467-17470

21 Wang JC, Zhang L, Fang WX, et al. Enhanced photoreduction $\mathrm{CO}_{2}$ activity over Direct Z-Scheme $\alpha-\mathrm{Fe}_{2} \mathrm{O}_{3} / \mathrm{Cu}_{2} \mathrm{O}$ heterostructures under visible light irradiation. ACS Appl Mater Interfaces, 2015, 7: 8631-8639

22 Wang Q, Hisatomi T, Ma SSK, et al. Core/shell structured La- and Rh-codoped $\mathrm{SrTiO}_{3}$ as a hydrogen evolution photocatalyst in Zscheme overall water splitting under visible light irradiation. Chem Mater, 2014, 26: 4144-4150

23 Iwashina $\mathrm{K}$, Iwase $\mathrm{A}, \mathrm{Ng} \mathrm{YH}$, et al. Z-schematic water splitting into $\mathrm{H}_{2}$ and $\mathrm{O}_{2}$ using metal sulfide as a hydrogen-evolving photocatalyst and reduced graphene oxide as a solid-state electron mediator. J Am Chem Soc, 2015, 137: 604-607

24 Ma K, Yehezkeli O, Domaille DW, et al. Enhanced hydrogen production from DNA-assembled Z-scheme $\mathrm{TiO}_{2}$-CdS photocatalyst systems. Angew Chem Int Ed, 2015, 54: 11490-11494

25 Si H, Kang Z, Liao Q, et al. Design and tailoring of patterned $\mathrm{ZnO}$ nanostructures for energy conversion applications. Sci China Mater, 2017, 60: 793-810

26 Liu Z, Zhao ZG, Miyauchi M. Efficient visible light active $\mathrm{CaFe}_{2} \mathrm{O}_{4} /$ $\mathrm{WO}_{3}$ based composite photocatalysts: effect of interfacial mod- ification. J Phys Chem C, 2009, 113: 17132-17137

27 Chen X, Huang X, Yi Z. Enhanced ethylene photodegradation performance of $\mathrm{g}-\mathrm{C}_{3} \mathrm{~N}_{4}-\mathrm{Ag}_{3} \mathrm{PO}_{4}$ composites with direct Z-scheme configuration. Chem Eur J, 2014, 20: 17590-17596

28 Iwase $\mathrm{A}, \mathrm{Ng} \mathrm{YH}$, Ishiguro $\mathrm{Y}$, et al. Reduced graphene oxide as a solid-state electron mediator in Z-scheme photocatalytic water splitting under visible light. J Am Chem Soc, 2011, 133: 1105411057

29 Li W, Feng C, Dai S, et al. Fabrication of sulfur-doped g- $\mathrm{C}_{3} \mathrm{~N}_{4} / \mathrm{Au} /$ CdS Z-scheme photocatalyst to improve the photocatalytic performance under visible light. Appl Catal B-Environ, 2015, 168-169: $465-471$

30 Xie $\mathrm{K}, \mathrm{Wu} \mathrm{Q}$, Wang $\mathrm{Y}$, et al. Electrochemical construction of Zscheme type $\mathrm{CdS}-\mathrm{Ag}-\mathrm{TiO}_{2}$ nanotube arrays with enhanced photocatalytic activity. Electrochem Commun, 2011, 13: 1469-1472

31 Li H, Yu H, Quan X, et al. Uncovering the key role of the Fermi level of the electron mediator in a Z-Scheme photocatalyst by detecting the charge transfer process of $\mathrm{WO}_{3}$-metal-gC $\mathrm{gC}_{4}$ (metal = $\mathrm{Cu}, \mathrm{Ag}, \mathrm{Au}$ ). ACS Appl Mater Interfaces, 2016, 8: 2111-2119

32 Li P, Zhou Y, Li H, et al. All-solid-state Z-scheme system arrays of $\mathrm{Fe}_{2} \mathrm{~V}_{4} \mathrm{O}_{13} / \mathrm{RGO} / \mathrm{CdS}$ for visible light-driving photocatalytic $\mathrm{CO}_{2}$ reduction into renewable hydrocarbon fuel. Chem Commun, 2015, 51: $800-803$

33 Jia Q, Iwase $\mathrm{A}$, Kudo A. $\mathrm{BiVO}_{4}-\mathrm{Ru} / \mathrm{SrTiO}_{3}: \mathrm{Rh}$ composite Zscheme photocatalyst for solar water splitting. Chem Sci, 2014, 5: 1513-1519

34 Ismail AA, Al-Sayari SA, Bahnemann DW. Photodeposition of precious metals onto mesoporous $\mathrm{TiO}_{2}$ nanocrystals with enhanced their photocatalytic activity for methanol oxidation. Catal Today, 2013, 209: 2-7

35 Fan J, Boettcher SW, Stucky GD. Nanoparticle assembly of ordered multicomponent mesostructured metal oxides via a versatile sol -gel process. Chem Mater, 2006, 18: 6391-6396

36 Tan $\mathrm{H}$, Zhao Z, Niu M, et al. A facile and versatile method for preparation of colored $\mathrm{TiO}_{2}$ with enhanced solar-driven photocatalytic activity. Nanoscale, 2014, 6: 10216-10223

37 Chen X, Burda C. The electronic origin of the visible-light absorption properties of C-, $\mathrm{N}$ - and S-doped $\mathrm{TiO}_{2}$ nanomaterials. J Am Chem Soc, 2008, 130: 5018-5019

Acknowledgements Sun $\mathrm{Z}$ thanks the financial support from the National Natural Science Foundation of China (21671011), Beijing High Talent Program, Beijing Natural Science Foundation (KZ201710005002). The authors thank China Postdoctoral Science Foundation, Beijing Postdoctoral Research Foundation, and Dongguan Program for International S\&T Cooperation. Zhao Z thanks the support from China Scholarship Council. This research was also supported by the National Science Foundation (DMR-1506661, Feng P).

Author contributions $Z$ hao $Z$ designed and engineered the samples; Zhao Z, Xing Y and Li H performed the experiments. Zhao Z, Sun Z and Feng $\mathrm{P}$ wrote the paper. All authors contributed to the general discussion.

Conflict of interest The authors declare that they have no conflict of interest.

Supplementary information Experimental details are available in the online version of the paper. 

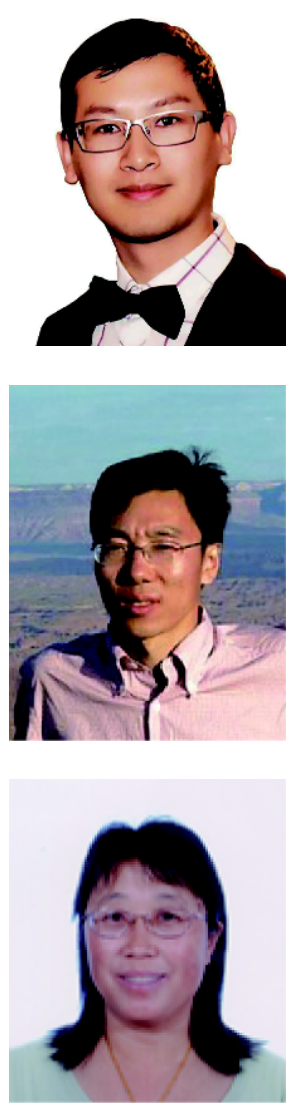

Zhao Zhao received his PhD degree from Changchun Institute of Optics, Fine Mechanics and Physics, Chinese Academy of Sciences, Changchun, China. He is currently a lecturer in the Key Laboratory of Functional Materials Physics and Chemistry of the Ministry of Education, Jilin Normal University. His main research area includes photocatalyst based on inorganic semiconductors.

Zaicheng Sun is a professor of Beijing Key Lab for Green Catalysis and Separation, Department of Chemistry and Chemical Engineering, College of Environmental and Energy Engineering, Beijing University of Technology, Beijing. China. His research interests are mainly on the photocatalytic nano materials for water splitting, $\mathrm{H}_{2}$ production, and selfcleaning optical coating, fluorescent carbon dots for theragnostics.

Pingyun Feng is a professor of the Department of Chemistry, University of California, Riverside, CA, USA. She received her PhD degree from the Department of Chemistry, University of California, Santa Barbara. Her research interest centers on the development of synthetic methodologies to prepare novel materials for energy conversion and storage. These materials integrate uniform porosity, high surface area, semi conductivity, optical property, photocatalytic, acid- or basecatalytic properties and have a variety of applications.

\section{构建高效可见光区分解水制氢的Z型 $\mathrm{CdS} / \mathrm{Cd} /$ 掺杂 $\mathrm{TiO}_{2}$ 光催化体系}

赵㻇 ${ }^{1,2,3,4}$, 邢艳波 ${ }^{1}$ 李海波 ${ }^{1}$ 冯萍云 ${ }^{*^{*}}$, 孙再成 ${ }^{{ }^{*}}$

摘要 构建 $\mathrm{Z}$ 型光催化体系是提高光生电荷分离效率和光催化活性的一种有效途径. 本文通过溶胶凝胶方法制备了 $\mathrm{Cd}$ 掺杂的 $\mathrm{TiO}_{2}$ 纳米颗 粒, 并通过一步 $\mathrm{NaBH}_{4}$ 固相热还原的方式在材料表面可控地引入氧空位 $\left(\mathrm{V}_{\mathrm{O}}\right)$, 同时掺入的 $\mathrm{Cd}^{2+}$ 可被还原为金属 $\mathrm{Cd}^{0}$ 纳米粒子 $\left(\right.$ 即 $\mathrm{R}-\mathrm{Cd}$ : $\left.\mathrm{TiO}_{2}\right)$. 进一步将获得的R-Cd: $\mathrm{TiO}_{2}$ 材料与硫嫝热水反应, 材料表面的 $\mathrm{V}_{\mathrm{O}}$ 可被 $\mathrm{S}^{2-}$ 替代, 同时部分金属 $\mathrm{Cd}^{0}$ 硫化, 从而获得 $\mathrm{CdS} / \mathrm{Cd} / \mathrm{d}-\mathrm{TiO} \mathrm{O}_{2} \mathrm{Z}$ 型光催化 复合材料. 研究结果表明该Z型光催化复合材料具有优异的模拟太阳光及可见光区光催化活性和稳定性. 通过实验分析证明构建这种全固 态金属-无机半导体Z型光催化复合材料, 金属介质层显著促进了光生电荷的分离与迁移; 此外, 由于 $\mathrm{CdS}$ 和 $\mathrm{d}-\mathrm{TiO}_{2}$ 在可见光区的光吸收作 用, 该 $\mathrm{CdS} / \mathrm{Cd} / \mathrm{d}-\mathrm{TiO}_{2} \mathrm{Z}$ 型光催化复合材料在可见光区的光催化活性获得了显著增强. 